\title{
Determinasi Kandungan Kadmium (Cd) Di Perairan Pantai Malalayang Sekitar Rumah Sakit Prof Kandou Manado
}

(Determination of Cadmium Content (Cd) in Malalayang Coastal Waters Around Hospital Prof Kandou Manado)

\section{Hulda Mamoribo ${ }^{1}$, Robert J. Rompas ${ }^{2}$, Ockstan J. Kalesaran ${ }^{2}$ \\ 1) Mahasiswa pada PS Budidaya Parairan FPIK Unsrat Manado \\ 2) Staf pengajar pada PS Budidaya Perairan FPIK Unsrat Manado \\ Email: okstankalesaran@yahoo.com}

\begin{abstract}
This research was conducted by purposive random sampling method with 3 points. Data were analyzed descriptively by comparing the environmental quality standard based on the Ministry of Environment No. 51. 2004. Results of laboratory analysis was the content of Cadmium (Cd) was still below the allowable threshold. Compared to Cd content of fresh water which was $0.0002 \mathrm{mg} / \mathrm{L}$, the Cd content found in this research was lower that was $0.0001 \mathrm{mg} / \mathrm{L}$.

Keywords: Kadmium (Cd), Logam berat, Baku Mutu, Pantai Malalayang, RS Prof Kandou.

\section{PENDAHULUAN}

Indonesia yang dikenal Negara Maritim memiliki laut dengan luas 5.193.250 $\mathrm{km}^{2}$ atau sekitar $2 / 3$ dari luas daratan, mempunyai fungsi yang sangat penting dalam pembangunan di Indonesia. Dengan kedalaman rata-rata 3.752 km berarti volume laut sekitar 19, 5 juta $\mathrm{km}^{2}$ (Effendi, 1997). Melihat angka tersebut mungkin ada yang berpikir laut merupakan waduk raksasa yang mampu menampung dan melarutkan bahan - bahan buangan hasil kegiatan manusia secara tidak terbatas tampa merusak kualitas dan mutu lingkungan laut itu sendiri.

Keadaan di Indonesia pada dewasa ini menunjukkan adanya perkembangan di bidang industri sangat

pesat walaupun kondisi ekonomi mengalami beberapa kendala. Kemajuan di bidang industri disuatu sisi sangat mengembirakan karena mampu menopang kehidupan manusia, tetapi di sisi lain mengancam kehidupan manusia, seperti buangan limbah yang tergolong B3 (Bahan Beracun Berbahaya) seperti cadmium (Cd).

Dampak yang bersifat negatif, dapat mengancam kegiatan manusia dan hewan, terutama limbah yang larut dalam air yang berwujud gas atau partikel terbawah oleh udara. Selain itu terdapat pula limbah yang berwujud padat dalam jumlah yang banyak yang bersumber dari limbah industri, kebocoran/tumpaan minyak dan juga berasal dari limbah
\end{abstract}


domestik dimana limbah-limbah tersebut dapat menimbulkan pencemaran lingkungan darat, udara dan laut (Rompas, 1995).

\section{Provinsi Sulawesi Utara,} khususnya kota Manado terdapat salah satu rumah sakit terbesar, yang banyak membuang limbah Rumah sakit seperti : Radioaktif (W) yang digunakan dalam melakukan ronsen (Sinar X) tidak di duga hasil buangan buangan limbah tersebut akan membahayakan lingkungan.

Kimia logam berat kadmium (Cd), adalah elemen toksik yang dapat berpengaruh pada sistim ekologi perairan sebab dikuatirkan limbah tersebut mengandung bahan berbahaya dan beracun (B3), yang dapat mengancam keseimbangan ekologi dan kelansungan hidup yang berlangsung di sekitar perairan laut tersebut.

Atas dasar uraian di atas, timbul gagasan untuk mengadakan penelitian mengenai determinasi kandungan $\mathrm{Cd}$ di perairan di sekitar drainase buangan (Rumah Sakit Prof, Kandou). berapa besar kandungan Cd yang ada di dalam perairan pantai, atas buangan air limbah drainase kearah laut sekitar untuk di teliti. Kandungan Cd di beberapa tempat dalam kawasan perairan Provinsi Sulawesi Utara, kadar nya relatif tinggi. Ada suatu dugaan di perairan teluk Manado Cd cukup tinggi dan elemen itu sangat berbahaya dalam tubuh. Elemen toksik ini yang diteliti dalam lingkungan perairan pantai di sekitar RS Prof Kandou.

Penelitian bertujuan mendeteksi kandungan Kadmium (Cd) yang terlarut di perairan pantai di sekitar Rumah Sakit Prof Kandou Manado.

\section{METODE PENELITIAN}

Penelitian ini dilaksanakan di lapangan dan laboratorium, berupa pengambilan sampel di perairan Malalayang (sekitar Rumah Sakit Umum Prof Kandou) dan selanjutnya Sampel dianalisis dilaboratorium HIPERKES Provinsi Sulawesi Utara.

\section{Alat dan Bahan}

Alat alat yang digunakan dapat dilihat pada tabel berikut:

Tabel 1. Alat -alat yang dipakai dalam penelitian

\begin{tabular}{|c|l|l|}
\hline No & \multicolumn{1}{|c|}{ Alat } & \multicolumn{1}{|c|}{ Kegunaan } \\
\hline 1 & $\begin{array}{l}\text { Labu } \\
\text { Erlenmeyer }\end{array}$ & Tempat Sampel \\
\hline 2 & Labu ukur & Tenpat Pengencer \\
\hline 3 & Pemanas & Memanaskan Sampel \\
\hline 4 & Gelas ukur & Mengukur Sampel \\
\hline 5 & Corong & Menyaring Sampel \\
\hline 6 & $\begin{array}{l}\text { Pipet dan } \\
\text { mikro pipet }\end{array}$ & Mengambil Sampel \\
\hline 7 & $\begin{array}{l}\text { ASS } \\
\text { Ektimasi Kandungan } \\
\text { Sampel }\end{array}$ \\
\hline 8 & Kertas Saring & Menyaring Sampel \\
\hline 9 & Gelas Piala & $\begin{array}{l}\text { Tempat destruksi } \\
\text { Sampel }\end{array}$ \\
\hline 10 & Kaca Arloji & Penutup Sampel \\
\hline 11 & Kamera & Dokumentasi \\
\hline
\end{tabular}


Bahan-bahan yang digunakan dapat dilihat pada table 2 .

Tabel 2. Bahan- bahan yang dipakai dalam penelitian

\begin{tabular}{|c|l|l|}
\hline No & Bahan & Kegunaan \\
\hline 1. & Sampel Air & objek Penelitian \\
\hline 2. & Aqudes & Pengenceran \\
\hline 3. & $\mathrm{HNO}_{3}$ Pekat & Proses Destruksi \\
\hline 4. & $\begin{array}{l}\text { Larutan } \\
\text { Logam }\end{array}$ & Larutan Baku cd \\
& & \\
\hline
\end{tabular}

\section{Teknik Pengambilan Sampel.}

Teknik Pengambilan sampel yang di lakukan dalam penelitian ini adalah metode sampling secara "purposive random" dengan 3 titik pengambilan. Untuk mendapatkan air sampel digunakan botol plastik, sampel air yang diperoleh dimasukkan kedalam botol dan diberi label (berdasarkan titik pengambilan) lalu dibawa ke laboratorium HIPERKES kemudian di analisis.

\section{Pengumpulan dan Analisis Data}

Data yang dikumpulkan dalam penelitian ini adalah kandungan parameter Cd. Data penelitian ini dianalisis secara deskriptif dengan mempertimbangkan faktor-faktor penentu kadar elemen-elemen tersebut diperairan tawar, laut dan membandingkan dengan Baku Mutu lingkungan berdasarkan Keputusan Menteri Negara Lingkungan Hidup Nomor: 51 Tahun 2004, Tentang Baku Mutu Air Laut. Untuk Biota Laut dan Wisata Bahari.

\section{HASIL DAN PEMBAHASAN}

Lokasi pengambilan sampel di aliran drainase RS Prof Kandou dan muara dekat pantai, dengan 3 titik yaitu ; titik I berada di drainase 100 meter sebelum ke pantai. Titik 2 terletak 50 meter sebelah kiri dari muara drainase dan titik 3 terletak 50 meter sebelah kanan dari muara drainase. Lokasi pengambilan sampel berdekatan dengan pemukiman masyarakat nelayan dan tempat tautan perahu.

Hasil analisis laboratorium pada ketiga titik pengambilan sampel air untuk kandungan terlarut parameter Kadmium(Cd) dapat disajikan pada tabel 3.

Tabel 3. Hasil Analisis Laboratorium Kandungan Kadmium (Cd) mg/l.

\begin{tabular}{|c|c|c|c|}
\hline $\begin{array}{l}\text { Titik } \\
\text { Pengambilan } \\
\text { Sampel }\end{array}$ & $\mathrm{mg} / \mathrm{L}$ & $\begin{array}{l}\text { Parameter } \\
\text { Kandungan } \\
\text { Yang } \\
\text { Terdeteksi }\end{array}$ & \begin{tabular}{|l} 
KEPUTUSAN \\
MENTERI \\
NEGARA \\
LINGKUNGAN \\
HIDUP NO.51 \\
THN 2004 BAKU
\end{tabular} \\
\hline $\begin{array}{l}\text { Air Tawar } \\
\text { Air Laut I } \\
\text { Air Laut II }\end{array}$ & $\begin{array}{l}\mathrm{mg} / \mathrm{L} \\
\mathrm{mg} / \mathrm{L} \\
\mathrm{mg} / \mathrm{L}\end{array}$ & $\begin{array}{l}0.0002 \\
0.0001 \\
0.0001\end{array}$ & $\begin{array}{l}\text { MUTU AIR } \\
\text { LAUT UNTUK } \\
\text { BIOTA LAUT. } \\
0.001 \mathrm{mg} / \mathrm{L} . \\
0.002 \mathrm{mg} / \mathrm{L} \\
\text { Untuk Wisata } \\
\text { Bahari. }\end{array}$ \\
\hline
\end{tabular}

Dari data tabel 3. menunjukkan bahwa konsentrasi cadmium masing-masing (Cd) adalah Air Tawar sebesar 0.0002.mg/L sedangkan pada Air laut I dan Air Laut II sebesar masing-masing sebesar $0.0001 \mathrm{mg}$ /L. Hasil konsentrasi tersebut dibandingkan dengan Baku Mutu berdasarkan Keputusan Menteri Negara lingkungan Hidup No. 51 
Tahun 2004 tentang Baku Mutu Air Laut untuk Biota Air Laut yang kadar maksimun adalah $0.001 \mathrm{mg} / \mathrm{L}$. sedangkan pada Baku Mutu untuk Wisata Bahari adalah 0,002 mg/L. Maka dapat dilihat bahwa kandungan cadmium (Cd) diperairan pantai malalayang 1 disekitar Rs. Prof Kandou berada dibawah ambang batas yang diperbolehkan. Hasil penelitian konsentrasi pada ke tiga titik dengan sampel menunjukan konsentrasi dibawah kandungan (Cd) dibawah ambang batas.

Senyawa kimia yang sangat beracun (toksis) bagi organism hidup diantaranya adalah senyawa kimia yangmempunyai bahan aktif dari logam berat seperti $\mathrm{Cd}, \mathrm{Pb}$, $\mathrm{Cu}$, As, $\mathrm{Cr}, \mathrm{Hg}$, dan $\mathrm{Ni}$. Logam berat cadmium (Cd) dapat berasal dari limbah industry, apabila masuk ke dalam tubuh organism dapat terakumulasi dalam tubuh sebagai racun dan sebagai penghalang kerja enzim dalam proses metabolism (World Bank, 1985; Noy-Meir, 1975; Wild, 1995 dalam Sunarto 2001). Logam berat yang masuk ke tubuh hewan umumnya tidak dikeluarkan lagi sehingga cenderung menumpuk di dalam tubuhnya (Nybakken, 1992).

Analisis kandungan Cd di perairan pantai Malalayang sekitar RS prof kandou masih dibawah ambang batas. Ini menandakan perairan tersebut bebas dari buangan limbah B3 (khusus Cd). Instalasi pengolahan air limbah (IPAL) RS cukup baik karena tidak membuang limbah B3/Cd ke saluran pemukiman yang mengalir ke pantai. Selain itu nelayan sekitar lokasi tidak membuang limbah pengecetan perahu ke perairan pantai Malalayang.
Apabila kandungan cadmium (Cd) telah terkonfermasi dengan organism perairan maka melalui rantai makanan akan mengganggu kehidupan manusia. Pengaruh racun yang ditimbulkan kadmium (Cd) sangat buruk, diantaranya penderita mengalami tekanan darah tinggi, kerusakan ginjal dan kerusakan jaringan tubuh. Kadmium adalah sebuah logam yang berpotensi racun sangat bahaya bagi lingkungan dan manusia karena jangka waktu terurai yang lama. (Rompas, M.D.1999).

Menurut Atdjas (2008) mengatakan Kadmium (Cd) merupakan bahan pencemaran organik/mineral yang dapat terakumulasi dalam perairan maupun dalam makanan. Secara umum masuk ke dalam perairan akan menjadi $\mathrm{Cd}^{+2}$ yang menyebabkan toksisitas perairan. Menurut Connel dan Miller (1995) mengatakan bahwa $\mathrm{Cd}^{+2}$ yang bersifat racun masuk kedalam tubuh tersebut, sedangkan menurut Erllangga (2007) bahwa dimana cadmium merupakan logam non eksisial yang tidak dapat didegradasi sehingga akan menyebabkan gangguan pada organ, insang dan ginjal.

Apabila kandungan cd telah terkontaminasi dengan organisasi perairan, maka melalui rantai makanan akan mengganggu kehidupan manusia. Pengaruh racun yang ditimbulkan oleh $\mathrm{Cd}$ sangat buruk, penderita mengalami tekanan darah tinggi.

Analisis kandungan kadmium di perairan pantai Malalayang sekitar Rumah Sakit Prof Kandou masih dibawah ambang batas (pada titik I 0,0002 mg/l). Ini menandakan perairan tersebut terbebas dari 
buangan limbah B3 (khusus Cd) . Instalasi pengelolahan air Limbah (IPAL) Rumah Sakit diduga cukup baik sehingga hasil buangan rumah sakit melalui IPAL seperti Ronsen, obat-obatan, hasil cucian, dapur, dikelola memalui IPAL, melalui drainase masuk ke perairan pantai Malalayang sehingga hasil dari kegiatan rumah sakit tidak menunjukkan adanya pencemaran lingkungan.

\section{KESIMPULAN}

Hasil analisis laboratorium yang diperoleh dibandingkan dengan Baku Mutu Lingkungan No. 51 Tahun 2004, dapat disimpulkan bahwa kandungan Kadmium (Cd) masih berada di bawah ambang batas yang diperbolehkan.

\section{DAFTAR PUSTAKA.}

Atdjas D. 2008. Dampak kadar cadmium (cd) dalam tubuh kerang hijau (Perma viridis) di daerah tambah muara karang teluk Jakarta terhadap kesehatan manusia. Program pasca sarjana ITS. Surabaya.

Connel DW, Miller GJ. 1995. Kimia ddan eleotaksio kalogi pencemaran. III Press. Jakarta
Effendi F. 1997 . Bahan Pencemar (Kimia)

Dan Metode Analisisnya Pada Kawasan Pesisir Dan Laut Secara Terpadu. Kerja sama ITS dengan Dirjen Dikti. Surabaya.

Erllangga. 2007, Efek Pencemaran Pencairan sungai kampau di Propinsi Riau terhadap ikan baung (Hemibagus meminrus) Tesis , Sekolah Pasca Sarjana IPB. Bogor.

Nybakken JW. 1992. Biology Laut; Studi Pendekatan Ekologis. Gramedia.

Rompas RJ. 1995 Kemampuan Tumbuhan Air Tumpeh (Monochoria vaganalis) Menyerap Logam Berat Hg dan Zn. Tesis Program Studi Ilmu Lingkungan, Program Pasca Sarjana UGM. Yokyakarta.

Rompas MD. 1999. Determinasi kandungan cd, $\mathrm{Cu}, \mathrm{pb}$ dan ni terlarut di perairan teluk buyat Skripsi. Fakultas perikanan dan Ilmu kelautan Unsrat. Manado.

Sunarto. 2001, Karakteristik, Pola Pita Protcin Anodonta Woodiana akibat terpapar Logam Berat Cadmium (Cd). Jurnal Ekosains Vol.III No.1. 